\title{
CONTENT OF NITRITES AND SALT AND CHEMICAL COMPOSITION OF SOME MEAT PRODUCTS
}

\author{
Darko Andronikov ${ }^{1}$, Aco Kuzelov ${ }^{2}$, Nako Taškov ${ }^{3}$, Dušica Saneva ${ }^{3}$, \\ Aco Janevski ${ }^{1}$, Kiro Mojsov ${ }^{1}$, Elenica Sofijanova ${ }^{4}$ \\ ${ }^{1}$ Faculty of Technology University ,, Goce Delčev“, Krste Misirkov bb, Štip, Republic of Macedonia \\ ${ }^{2}$ Faculty of Agriculture, University ,, Goce Delčev“", Krste Misirkov bb, Štip, Republic of Macedonia \\ ${ }^{3}$ Faculty of Tourism and business logistics University ,, Goce Delčev“, \\ Krste Misirkov bb, Štip, Republic of Macedonia \\ ${ }^{4}$ Faculty of Economics, University ,, Goce Delčev“", Krste Misirkov bb, Štip, Republic of Macedonia \\ darko.andronikov@ugd.edu.mk
}

\begin{abstract}
The aim of our research was to examine the content of nitrite and salt and chemical composition of the shaped pieces of meat from the neck, shoulder, boneless and fresh bacon (pancetta) and understanding of consumer behavior in the market when choosing the appropriate meat product. The test used 12 pieces of shaped meat and 3 pieces of pork, neck, shoulder, boneless and bacon. All parts are separately measured before and after injection and heat treatment. Chemical composition and $\mathrm{pH}$ where tested before and after heat treatment. At the same time, microbiological assays are carried out on samples of meat (all four categories of meat) before and after injection and heat treatment. The content of nitrites and salt examined the finished product. The largest growth of the injection is found in pork boneless $(20.8 \%)$ and the lowest in pancetta $(6.46 \%)$. The lowest weight loss after heat treatment is found in pancetta $(0.77 \%)$, while the largest weight loss has the neck $(8 \%)$. The content of the salt in the finished meat products ranges from 1.65 and $2.38 \%$, while the content of nitrite ranging from 14 and $22(\mathrm{mg} / \mathrm{kg})$. After injection and thermal treatment water content and fat are reduced, while the protein content increased in the finished product: neck, shoulder and boneless. In finished products not found bacteria of the following types: Clostridium, Staphylococus, Proteus, Escherichia. Total number of bacteria (bacillus) showed a decrease after heat treatment in all four categories of meat.
\end{abstract}

Key words: nitrites; salt; chemical composition; weight loss during heat treatment; microorganisms

\section{СОДРЖИНА НА НИТРИТИ, СОЛ И ХЕМИСКИОТ СОСТАВ НА НЕКОИ МЕСНИ ПРОИЗВОДИ}

Целта на нашето истражување беше да се испита содржината на нитрити и сол и на хемискиот состав на обликувани парчиња месо од пределот на вратот, плешката, карето и свежата сланина (панцета) и да се разбере однесувањето на потрошувачите на пазарот при изборот на соодветен месен производ. За испитување се употребени 12 парчиња обликувано месо, и тоа по 3 парчиња од свински: врат, плешка, каре и сланина. Сите парчиња се мерени посебно пред и по инјектирање и по термичка обработка. Хемискиот состав и $\mathrm{pH}$ се испитувани пред и по термичкиот третман. Во исто време се извршени микробиолошки анализи на примероците од месо (во сите четири категории месо) пред и по инјектирањето и по термичкиот третман. Содржината на нитрити и сол се испита на готовиот производ. Најголем прираст по инјектирањето е констатиран во свинското каре $(20.8 \%)$, а најнизок во панцетата (6.46 \%). Најмало губење на тежина (кало) по термичкиот третман е констатирано кај панцетата $(0.77 \%)$, додека најголемо кало има кај вратот (8 \%). Содржината на сол во готовите производи од месо се движи од 1.65 и $2.38 \%$, додека содржината на нитрити се движи од 14 и $22 \mathrm{mg} / \mathrm{kg}$. По инјектирањето и термичкиот третман содржината на вода и масти е намалена, додека содржината на протеини е зголемена во готовите производи: вратот, плешката и карето. Во готовите производи не се пронајдени бактерии од следните типови: Clostridium, Staphylococcus, Proteus, Escherichia. Вкупниот број на бактерии (bacillus) покажа намалување по термичкиот третман во сите четири категории месо.

Клучни зборови: нитрити; сол; хемиски состав; губење на тежина (кало) при термичка обработка; микроорганизми 


\section{INTRODUCTION}

How would use the technical possibilities of preservation of meat, such as: physical assets (refrigeration and freezing), chemicals (salt, nitrate and nitrite) and thermal resources (pretensions, boiling and smoking) for produce the different semidry smoked products (sausages, neck, shoulder, boneless, bacon). Sustainability of the mentioned products is increasing, but it is different and depends on the type of product (Vuković et al. 2004). In fresh sausage sustainability is the shortest, longer is in semidry meat products, and is the longest in dry products of meat (even up to 1 year). Among the various methods of conservations of meat, salting and brining is one of the oldest. Brining of the meat comprises: adding salt and various additives (nitrate, nitrite, phosphate, sugars - glucose, ascorbic acid, etc.) and dissolved in water spices. There is a wet and dry curing meat (Beganović, 1975; Bem and Adamić, 1991; Beličoski et al., 1997; Perić, 2007).

Wet curing is done in several ways: by dipping the meat in a solution of a curing compound or following the injection brine into the meat. Today brine meat is injected with a very injection or needle or picl injector where brine is injected into the meat quickly and evenly. As a result of brining in meat has increased sustainability while improving its sensory properties and above all the smell, taste, color and turgidity. In the production of semidry products are used all the mentioned funds, in order to reduce the number of unwanted bacteria while meat and meat products would increase durability. But every technical processing of meat has its drawbacks, and the meat loses some of its nutrients and loses its weight by evaporation - drying (weight loss). The aim of our study was to examine the content of nitrites and salt, chemical composition and microbiology of some pork products: neck, shoulder, boneless and fresh bacon in different times (before and after injection, and after heat treatment).

\section{MATERIAL AND METHODS}

As test material was taken fresh boneless pork meat and fresh bacon of the pigs breed Dalant. Pigs are slaughtered and processed after reaching the live weight of about 110 to $120 \mathrm{~kg}$. After slaughter, primary processing and cooling of pig halves on the temperature of $+4{ }^{\circ} \mathrm{C}$ for 24 hours was performed classification and categorization of pig halves of main parts and categories. The 3 pieces of pork: neck, shoulder, boneless and bacon (pancetta) are measured on electronic weigh (each piece separately) where was determined their weight before brining. After brining was performed measurement again in order to determine the mass of the pieces after the meat brining. The brine recipe that brined slices of meat with the needle injection - picl injector is composed of: salt, nitrite, malkovita, and water. Preparation malkovita is product of firm REGIS SA and is made of: stabilizer for consistency of meat E 451, E 452, sugars, glucose, antioxidant E 301, E 316, flavorings E 621, flavors, salt and spices extracts. Pork neck and shoulder injected $50-60 \%$, pork boneless injected $35-45 \%$, pork bacon (pancetta) injected $25-35 \%$. The thermal treatment of neck, shoulder, boneless pork and pancetta is performed at following recipe: $15 \mathrm{~min}$. drying on Tk $60{ }^{\circ} \mathrm{C}, 45$ min. smoking with hot smoke on Tk $65{ }^{\circ} \mathrm{C}, 45$ min. smoking with thick smoke on Tk $70{ }^{\circ} \mathrm{C}, 120$ min. baking with smoking Tk $85{ }^{\circ} \mathrm{C}$, Tcp $72{ }^{\circ} \mathrm{C}$. $\mathrm{pH}$ value was determined by a digital $\mathrm{pH}$ meter “Testo 230" (Testo, Germany, 2004).

\section{Chemical analyses}

Total nitrogen $(\mathrm{TN})$ was determined according to the Kjeldahl method. Moisture content was determined by drying at $103 \pm 2{ }^{\circ} \mathrm{C}$ to constant mass. The intramuscular fat content was determined according to AOAC International method, with petroleum ether as solvent. Ash was determined by burning and combustion $(4-5 \mathrm{~h})$ at $525-$ $550{ }^{\circ} \mathrm{C}$ [Ash of Meat, 1997]. Content of sodium chloride was determined by ISO 1841-1/1999. Content of nitrite were determined by ISO 2918$1 / 1999$.

\section{Microbiological analysis}

Following bacteria were determined: Total bacteria (bacillus) number - ISO 4833/2003. Sown on nutrient agar to $37^{\circ} \mathrm{C}$ during 24 hours. Staphylococcus ISO 6888-1/1999. Sown on ETGP agar (barit parker agar) after termostating on $37{ }^{\circ} \mathrm{C}$ during 24 hours. Enterobacteriaceae ISO 215281/2004; ISO 21528-2/2009. Escherichia coli are sown on lactoza bujon and brilliant green, thermostated on $37^{\circ} \mathrm{C}$ during 24-48 hours. Clostridium sown on sulfiten agar, thermostated on $37{ }^{\circ} \mathrm{C}$ during 24-48 hours. Data were transformed into $\log 10$ $\mathrm{CFU} / \mathrm{g}$ before comparison of means. The results were statistically processed using mathematical program Microsoft EXEL ANOVA (single factor) $2009 / 2013$. 


\section{RESULTS AND DISCUSSION}

Results of average weight of pieces of meat before injection, after injection and after heat treatment are given in Table 1. From Table 1, it is seen that the lowest weight before brining has boneless pork pieces $(0.422 \mathrm{~g})$ and the highest mass has pork neck pieces $1.080 \mathrm{~kg}$. The lowest mass per injection has pork boneless $(0.528 \mathrm{~g})$ and the largest pork neck $1.220 \mathrm{~kg}$. The lowest mass after heat treatment has boneless pork $(0.418 \mathrm{~kg})$ and the largest pork neck $(0.988 \mathrm{~kg})$. The largest growth after injecting was determined in the boneless pork $(20.8 \%)$ and the lowest in pancetta $(6.46$ $\%)$. The lowest weight loss after heat treatment was observed in pancetta $(0.77 \%)$ while the largest weight loss in a pork neck $(8 \%)$. In pork shoulder is not determined mass loss but a small insignificant increase is likely due to better reception of the brine in the meat of the shoulder. Our results were similar to the results obtained by Stamenković et al., 2003.

The results of microbiological analysis of pieces of meat are shown in Table 2. The lowest microbial contamination before brining in terms of total number of bacteria (bacillus) in a pork neck $2.80 \log \mathrm{CFU} / \mathrm{g}$ and has the largest microbiological contamination in panceta $3.85 \mathrm{log} \mathrm{CFU} / \mathrm{g}$. Same is the case after injected. After heat treatment of all tested products microbiological analysis showed a reduction of the total number of bacteria (bacillus), the lowest values determined in pork neck $1.08 \mathrm{log}$ $\mathrm{CFU} / \mathrm{g}$ while the largest values determined in pork bacon (pancetta) $1.22 \log \mathrm{CFU} / \mathrm{g}$.

Table 1

Average weight of pieces of meat before injection, after injection and after heat treatment

\begin{tabular}{lccc}
\hline \hline \multirow{2}{*}{ Product name } & \multicolumn{3}{c}{ Average weight $(\mathrm{X} \pm \mathrm{Sd})$} \\
\hline & Before injection & After injection & After heat treatment \\
\hline Pork neck & $1.080 \pm 0.58$ & $1.220 \pm 0.88$ & $0.988 \pm 0.40$ \\
\hline Pork shoulder & $0.580 \pm 0.18$ & $0.628 \pm 0.12$ & $0.582 \pm 0.22$ \\
\hline Pork boneless & $0.422 \pm 0.15$ & $0.528 \pm 0.82$ & $0.418 \pm 0.25$ \\
\hline Pork bacon (pancetta) & $0.522 \pm 0.10$ & $0.558 \pm 0.28$ & $0.518 \pm 0.42$ \\
\hline \hline
\end{tabular}

$\mathrm{X}$ - mean, $\mathrm{Sd}-$ standard deviation; number of pieces $=3$

Table 2

Results of $p H$ value before and after thermic treatment and content of salt and nitrite in final products treatment $(X \pm S d)$

\begin{tabular}{lcccc}
\hline \hline Product name & Pork neck & Pork shoulder & Pork boneless & Pork bacon (panceta) \\
\hline pH before TT & $5.41 \pm 0.54$ & $5.42 \pm 0.45$ & $5.49 \pm 0.32$ & $5.26 \pm 0.56$ \\
\hline pH after TT & $5.81 \pm 0.46$ & $5.87 \pm 0.58$ & $5.74 \pm 0.14$ & $5.79 \pm 0.39$ \\
\hline salt * $(\%)$ & $2.22 \pm 0.74$ & $1.97 \pm 0.82$ & $1.65 \pm 0.59$ & $2.38 \pm 0.93$ \\
\hline nitrite* $(\mathrm{mg} / \mathrm{kg})$ & $20 \pm 0.23$ & $18 \pm 0.38$ & $14 \pm 0.18$ & $22 \pm 0.42$ \\
\hline \hline
\end{tabular}

Results of $\mathrm{pH}$ value before and after thermic treatment and content of salt and nitrite in final products are given in Table 2. $\mathrm{pH}$ value before thermic treatment ranges from 5.26 to 5.49 until $\mathrm{pH}$ after thermic treatment ranges from 5.74 to 5.81. Content of the salt in the finished meat product is between 1.65 and of $2.38 \%$, while the nitrite content is between 14 and $22 \mathrm{mg} / \mathrm{kg}$. The lowest
$\mathrm{pH}$ value is determined in panceta 5.26 and the highest value for pork neck 5.81. The lowest content of salt and nitrite was determined in pork boneless (1.65 vs 14) while the highest in pancetta ( 2.38 vs 22 ). Our results for nitrite and salt were similar to the results obtained by Prica et al. 2007; Perunović et al. 2002; Stamenković 2004. 
Results of chemical composition on pieces before and after thermic treatment are given in Table 3 . The content of water in raw meat pieces ranges from 41.37 to $74.36 \%$. The lowest water content found in pancetta and the highest in pork neck. Water content after the heat treatment increased in pancetta $(57.30 \%)$ while the remaining pieces of meat cut decreased (68.82 to $69.54 \%$ ).
Generally, the content of fat in pork neck, shoulder and boneless ranges from 4.21 to $9.24 \%$, while in pancetta this percentage is slightly higher $44.19 \%$. After heat treatment fat decreased in all pieces of meat.

The lowest fat content after thermal processing found in pork neck $(3.22 \%)$ while the highest in pancetta $(25.61 \%)$.

Table 3

Results of chemical composition on pieces before and after thermic treatment ( $X \pm S d)$

\begin{tabular}{lcccc}
\hline & Pork neck & Pork shoulder & Pork boneless & Pork bacon (pancetta) \\
\hline Water & $74.36 \pm 0.98$ & $70.57 \pm 0.75$ & $71.18 \pm 0.28$ & $41.37 \pm 0.49$ \\
Water after TT & $69.22 \pm 0.65$ & $69.54 \pm 0.15$ & $68.82 \pm 0.18$ & $57.30 \pm 0.61$ \\
Fats & $4.21 \pm 0.43$ & $9.24 \pm 0.39$ & $7.47 \pm 0.83$ & $44.19 \pm 0.21$ \\
Fats after TT & $3.22 \pm 0.51$ & $4.28 \pm 0.54$ & $4.64 \pm 0.77$ & $25.61 \pm 0.34$ \\
Proteins & $19.96 \pm 0.22$ & $18.94 \pm 0.29$ & $20.51 \pm 0.63$ & $13.38 \pm 0.53$ \\
Proteins after TT & $21.95 \pm 0.37$ & $21.18 \pm 0.73$ & $22.22 \pm 0.91$ & $13.56 \pm 0.54$ \\
Ash & $1.20 \pm 0.17$ & $1.12 \pm 0.09$ & $1.05 \pm 0.02$ & $1.17 \pm 0.09$ \\
Ash after TT & $3.46 \pm 0.10$ & $3.62 \pm 0.18$ & $3.32 \pm 0.08$ & $3.40 \pm 0.04$ \\
\hline \hline
\end{tabular}

$\mathrm{X}$ - mean, $\mathrm{Sd}$ - standard deviation; number of pieces $n=3$

The content of protein in the thermally untreated pieces of meat is from $13.38 \%$ to $20.51 \%$. The lowest protein content found in pancetta $(13.38 \%)$ while the highest in pork boneless $(20.51 \%)$. The content of protein after heat treatment increased by a few percent in all the pieces of meat.

Statistically, the content of minerals in raw pieces of meat is from 1.05 to $1.20 \%$. Tight connection between the injected amounts of the salt and content of minerals found in the four established groups of pieces of meat. The content of minerals by heat treatment ranges from $3.32 \%$ in pork boneless to $3.62 \%$ in pork shoulder.

Our results for chemical composition were similar to the results obtained by Okanović et al. 2006; Medić et al. 2012; Pleadin et al. 2013; Cvrtila et al. 2014.

The results of microbiological analysis of pieces of meat are shown Table 4 . The lowest microbial contamination before brining in terms of total number of bacteria (bacillus) in a pork neck $2.80 \log \mathrm{CFU} / \mathrm{g}$ and has the largest microbiological contamination in pancetta $3.85 \log \mathrm{CFU} / \mathrm{g}$. Same is the case after injected. After heat treatment of all tested products microbiological analysis showed a reduction of the total number of bacteria (bacillus), the lowest values determined in pork neck $1.08 \mathrm{log}$ $\mathrm{CFU} / \mathrm{g}$ while the largest values determined in pork bacon (pancetta) $1.22 \log$ CFU/g. Our results disagree with the results of Kuzelov et al. 2013.

\section{Table 4}

Microbiological picture (total number of bacteria (bacillus)) of pieces of meat before injection, after injection and after heat treatment $(\log C F U / g)$

\begin{tabular}{llll}
\hline \hline Product name & $\begin{array}{l}\text { Before } \\
\text { injection }\end{array}$ & $\begin{array}{l}\text { After } \\
\text { injection }\end{array}$ & $\begin{array}{l}\text { After heat } \\
\text { treatment }\end{array}$ \\
\hline Pork neck & $2.80 \pm 0.18$ & $2.98 \pm 0.15$ & $1.08 \pm 0.02$ \\
Pork shoulder & $3.28 \pm 0.08$ & $3.42 \pm 0.23$ & $1.10 \pm 0.04$ \\
Pork boneless & $3.52 \pm 0.21$ & $3.78 \pm 0.31$ & $1.18 \pm 0.09$ \\
Pork bacon (pancetta) & $3.85 \pm 0.09$ & $4.20 \pm 0.03$ & $1.22 \pm 0.07$ \\
\hline
\end{tabular}

$\mathrm{X}-$ mean, $\mathrm{Sd}-$ standard deviation; number of pieces $n=3$ 


\section{CONCLUSION}

The obtained results show that the brine which inject and set parameters of heat treatment the best affect has on pork shoulder. The contents of salt and nitrite are within the prescribed limits. Brine and heat treatment changed the chemical composition of all meat products where in the content of water and fat is reduced while the content of protein and minerals is increased. No bacteria are found from the following types of Clostridium, Staphylocoscus, Proteus, Escherichia, and the total number of bacteria (bacillus) showed a decrease of bacteria after heat treatment in all four categories of meat. After injection in all pieces of pork, total number of bacteria is slightly increased but after heat treatment the total number of bacteria was minimal. From this we can conclude that the hygiene conditions in which the course of this experiment were flawless.

\section{REFERENCES}

[1] Ash of Meat, AOAC Official Method No.920.153, AOAC International, Gaithersburg, MD, USA, 1997.

[2] Beganović, A. H.: Mikrobiologija mesa i mesnih prerađevina. Univerzitet u Sarajevu, 1975, pp. 14-19.

[3] Beličoski, S., Kuzelov, A., Pejkovski, Z., Stojanovski, M.: Effect of tumbling upon yield of smoked pork. Macedonian Agricultural Review, 44, 2, pp. 75-79 (1997).

[4] Bem, Z., Adamić, J.: Mikrobiologija mesa i proizvoda od mesa, Tehnološki fakultet, Novi Sad, pp. 91-102 (1991).

[5] Cvrtila Fleck, Ž., Večkovec, A. M., Špoljarić, D., Mršić, G., Srečec, S., Špiranec, K., Mihelić, D., Njari, B., Kozačinski, L., Popović, M.: Chemical evaluation of the quality of meat originating from pigs vaccinated with experimental bivalent vaccine against colidiarrhoea and colienterotoxemia. MESO: Prvi hrvatski časopis o mesu, Vol. XVI, No. 1, 71-74 (2014).

[6] Enterobacteriaceae, ISO 21528 - 1/ 2004; ISO 21528 - 2, 2009.

[7] Fat (Crude) in Meat and Meat Products, AOAC Official Method No. 991.36, AOAC International, Gaithersburg, MD, USA, 1997.
[8] Kuzelov, A., Dimitrovski, Z., Naneva, D., Taškov, N., Andronikov, D,: Microbiological status of smoked meat products. International scientific on line journal "Science \& Technologies", 3 (5),16-18 (2013).

[9] Medić, H., Horvat, M., Heigl, M., Vidaček, S., Marušić, N., Janči, T.: Utjecaj dodatka laktata na kvalitetu svježe mariniranog mesa. Meso: Prvi hrvatski časopis o mesu, Vol. XIV, No. 2, 132-137 (2012).

[10] Moisture in Meat, AOAC Official Method No. 950.46: AOAC International, Gaithersburg, MD, USA, 1997.

[11] Nitrogen in Meat, AOAC Official Method No. 928.08: AOAC International, Gaithersburg, MD, USA, 1997.

[12] Okanović, Đ., B, Mihajlović B., Lilić S.: Uticaj mehanićkog tretmana tokom salamurenja na neka svojstva dimljene svinjske pećenice. Biotechnology in Animal Husbandry 22 (5-6), 99-107 (2006).

[13] Perić, T., Đorđevič, T. S.: Proizvodnja kobasica i suhomesnatih proizvoda, Poljo Knjiga Beograd 2007, 54 75.

[14] Perunović, M., Ivanović, M., Bulatović, A., Zivković, D.: Uticaj različitih aditiva na tehnološka svojstva dimljene svinske pečenice. Tehnologija mesa, 43 (1-2), 43-46 (2002).

[15] Pleadin, J., Vahčić, N., Perši, N., Kovačević, D.: Variability of physico-chemical and sensory characteristics of autochthonous meat products between producer households. Meso: Prvi hrvatski časopis o mesu, Vol. XV No. 2, 122-131 (2013).

[16] Prica, Nadežda., Petrović, Jelena, Rackov, Olga: Sadržaj nitrita i ukupnog fosfora u proizvodima od mesa različitih proizvođača sa teritorije Južnobačkog i Sremskog okruga tokom 2006 godine. Tehnologija mesa 48, 5-6, 225-229 (2007).

[17] Salt $(\mathrm{NaCl})$ in Meat and Meat products AOAC Official Method No. 950.46: AOAC International, Gaithersburg, MD, USA, (1997).

[18] Stamenković, T.: Upotreba kuhinjske soli u proizodima od mesa. Tehnologija mesa 45 (5-6), 170-176 (2004).

[19] Stamenković, T., Simić, N., Jovanović, S., Milosavljević, T.: Gubitak mase, senzorna svojstva, hemijski pokazatelji i mikrobiološka ispravnost smrznute salamine upakovane u vakuumu.Tehnologija mesa 44 (1-2), 85-92 (2003).

[20] Staphylococcus, Official Method ISO 6888 - 1, 1999.

[21] Total bacteria (bacillus) number, Official Method ISO 4833, 2003.

[22] Vuković, I., Milanović-Stevanović, M.: Upotreba i deklarisanje aditiva u proizvodima od mesa - nova zakonska regulativa. Tehnologija mesa, 45, 5-6, 212-218 (2004). 